\title{
内陸大地震発生前後の震源域周辺の地震活動
}

\author{
気象研究所* 吉田明夫・高山博之

\section{Preceding and Succeeding Seismic Activities in the Circumferential Areas of the Focal Regions of Large Intraplate Earthquakes}

\author{
Akio Yoshida and Hiroyuki TaKayama \\ Meteorological Research Institute 1-1 Nagamine, Tsukuba, Ibaraki 305, Japan \\ (Received February 3, 1993; Accepted April 13, 1993)
}

\begin{abstract}
Seismic activities in and around the focal regions are investigated for 13 large intraplate earthquakes with $M \geqq 6.5$ which occurred in the Japanese islands during the period 1941 through 1990. It is found that (1) for all of these earthquakes, one or more large earthquakes with $M \geqq 6$ occurred at epicentral distances of less than $100 \mathrm{~km}$ within 15 years before their occurrence. Further, for 10 earthquakes among the 13 , one or two large earthquakes with $M \geqq 6$ occurred at epicentral distances of less than $100 \mathrm{~km}$ within 10 years after their occurrence. (2) Migrational tendency with a velocity at several $\mathrm{km} / \mathrm{y}$ ear is recognized in the occurrence of these large earthquakes. (3) Precursory activities are observed at epicentral distances of $50-100 \mathrm{~km}$ in the period 8-10 years before most of the large earthquakes. Sometimes a moderate earthquake with $M 4-5$ is also seen at the same period close to the focal regions. (4) Quiescence usually appears in and around the focal regions after the precursory activities. In some cases the quiescence continues until the occurrence of the main shock, while in other cases seismicity becomes active 1-3 years before the main shock. (5) There is a noticeable difference in the magnitude of influence on the stress field in the circumferential areas between $M 7$ class earthquakes and $M 6$ class earthquakes. (6) For $M 6$ class earthquakes remarkable quiescence is observed before their occurrence, and (7) it is rather rare that another large earthquake occurs following them in their circumferential areas.
\end{abstract}

Key words: Intraplate earthquake, Successiveness, Migration, Quiescence, Precursory activity.

\section{§1.はじめに}

内陸大地震の発生前に, その震源近傍あるいは周辺地 域で何らかの特徴的なサイスミシティパターンが見られ るだろうか. 海溝沿いのプレート間地震の場合には, 震源 域とその周辺の地震活動が前兆的に低下することはよく 知られていて [例えば MoGI (1969); KELlEHER and SAVINo (1975); 宮岡・吉田 (1993)]，それを基に地震が 予知された例もある [例えば宇津 (1972); OHTAKE et al. (1977)]. MogI (1969) はまた, 震源域で静穏化が生じた 時, その周辺では逆に地震活動が活発化する, いわゆる ドーナッパターンが見られることを指摘している。

MoGI (1979) のいわゆる第二種空白域という概念は, 常時地震活動がある程度高いところで有効であり, あと

* \%305 茨城県つくば市長峰 1-1
あと活動が低いところでは, 空白域が認められたとして あ, それが前兆現象としての静穏化を現しているのか, 単に地震活動が不活発なブロックの存在を示しているだ けなのかまず判別する必要がある，また，静穏化である としても，それがいつよ゙の範囲で生じたものかを特定す るのは容易ではない，このような状況の下では，静稳化 現象よりも何らかの異常な先駆的地震活動に注意を向け るほうが実際的といえよう。

関谷 (1976), SEKIYA (1977) は内陸大地震の数年から 10 数年前に, 震源域周辺で続発的な地震活動がしばし ば認められることに注目して，そうした活動から本震発 生までの期間と本震の $M$ との関係を論じた．勝又・浜 田 (1985) は $M 6$ 以上の浅い内陸大地震に数年から 10 年程度先行して, その震源域もしくは断層の延長線上ご く近傍で $M 4.5$ から M 5.5 の地震が発生している例を 
いくつか見つけ，それらが中期的前兆である可能性に注 意している. また, 鈴木 (1985) は, 関谷 (1976) が指摘 したような, 震源域近傍に見られる先駆的活動を内陸, 海域を問わず広範に調查し，それから本震発生までの期 間と本震のマグニチュードとの間に一見明瞭な相関が見 られることを示した. 外国の例では, ニュージーランド とカリフォルニアに発生した M 4.9 からM 7.1 の 11 個 の地震について, やはり, 先駆的群発地震が存在すると ともに，本震のマグニチュードとその先行時間との間に 関谷 (1976) や鈴木 (1985) が示したの之同様な関係の認 められることが, Evison (1977) によって指摘されてい る.これらの研究では, 何をもって先駆的活動, あるい は先駆的地震と見なすかについて定義がいま一つ明瞭で ないところがあるが，もし指摘されているような活動が 実際に大地震の発生之関連するものであり，それらが現 れた時点で的確にそれと識別できたなら，それは内陸地 震の中期的予知にとって確かに非常に有用であろう. ま た，たとえその時点で識別は困難であったとしても，そ うした現象が一般的に見られるものであれば，地震発生 過程を解明するうえで一つの手がかりとなるであろう.

ここでは上のような考えの下に, 特に内陸被害地震を 念頭において，1941 1990 年に発生した M 6.5 以上の 13 個の地震について, その震源域周辺のかなり広い範 囲にわたる活動の変化を調べてみた，対象とした地震の

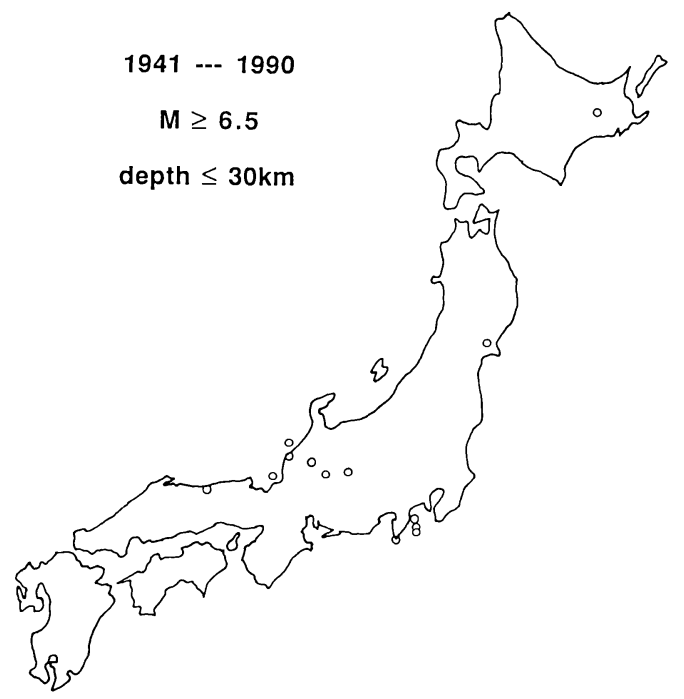

Fig. 1. Epicenters of earthquakes with $M \geqq 6.5$, depth $\leqq 30 \mathrm{~km}$, which occurred during the period 1941 through 1990 in the Japanese islands. Seismic activities in and around the focal regions of these earthquakes are investigated.
震央を Fig. 1 に示してある. この期間, 内陸に発生した $M 6.5$ 以上の浅い地震は, この他に 1945 年三河地震 $(M$ 6.8), 1948 年日高川地震 $(M 6.7)$ があるが, これらはそ れぞれ 1944 年東南海地震 $(M 8.0), 1946$ 年南海道地震 $(M 8.1)$ の広義の余震と見なされるので調查対象からは ずした。なお，用いたデー夕は気象庁地震月報によって いる.

上述の地震について, それらの震源域周辺の活動の変 化を, 相互に比較対照しながら共通のレベルで論じるこ とができるのは M 4 の地震が限度である[例えば高 山・吉田 (1992)]. そこで本論文では, 先駆的活動及び 静穏化現象を調べるにあたっては $M 4$ 以上の地震に関 して見ることとし， $M 5$ 以上， $M 6$ 以上の地震のみを取 りだした時の特徵的なパターンについてもそれぞれ別に 論じた. 82 ではまず $M 6$ 以上の地震に着目した時の続 発性と移動性について述べる.

\section{§2． 続発性と移動性}

Figs. 2(a), (b), (c) は 1952 年大聖寺沖地震 ( $M$ 6.5), 1969 年岐阜県中部地震 $(M 6.6), 1974$ 年伊豆半島沖地震 (M6.9)について, その周辺域で, いっどのくらい離れて $M 6$ 以上の地震が発生しているかを示したあのである. これら 3 つの場合いずれにおいても, それぞれの地震か ら前後 10 年以内, $80 \mathrm{~km}$ 以内に $M 6$ 以上の地震が 1 個 ないし 2 個起きていることがわかるが, それらの地震の 相対的な震央距離や発生時期は同じではない。しかし， これらの図を重ね合わせてみると, Fig. 2(d) に示すよう に, 震央距離が近いところでは時間的にも近接して, ま た遠いところではそれに比例するように離れて，M $６$ 以 上の地震が発生している傾向が見られる.すななわち,こ れら大きな地震の発生には, 見かけ上, 震央が約数 $\mathrm{km} /$ 年の速度で移動していくパターンが認められる.

ここで，特に指摘しておきたいことは, Figs. 2(a), (b), (c) のような図を, 81 で述べた $M 6.5$ 以上の 13 個の地 震についてそれぞれつくってみると, Fig. 3(a) に示すよ うに, そのすべてについて, 15 年以内, 震央距離 100 $\mathrm{km}$ 以内に $M 6$ 以上の地震がその前に発生しているこ とである（福井地震と長野県西部地震を除いて 10 年以 内). また, その後 10 年以内には, 13 個中 10 個の地震 について, 震央距離 $100 \mathrm{~km}$ 以内に $M 6$ 以上の地震が 発生している (Fig. 3(b)). 起きていないのは 1967 年弟 子屈地震と 1984 年長野県西部地震, 1990 年伊豆大島 近海地震だけで, 後の 2 つについては地震後まだ 10 年 経過しておらず，その周辺で $M 6$ 以上の地震が近い将 来に発生する可能性が残っている。 こうした事実は, 内 陸の $M 6.5$ 以上の地震は一個だけ孤立して起きること 

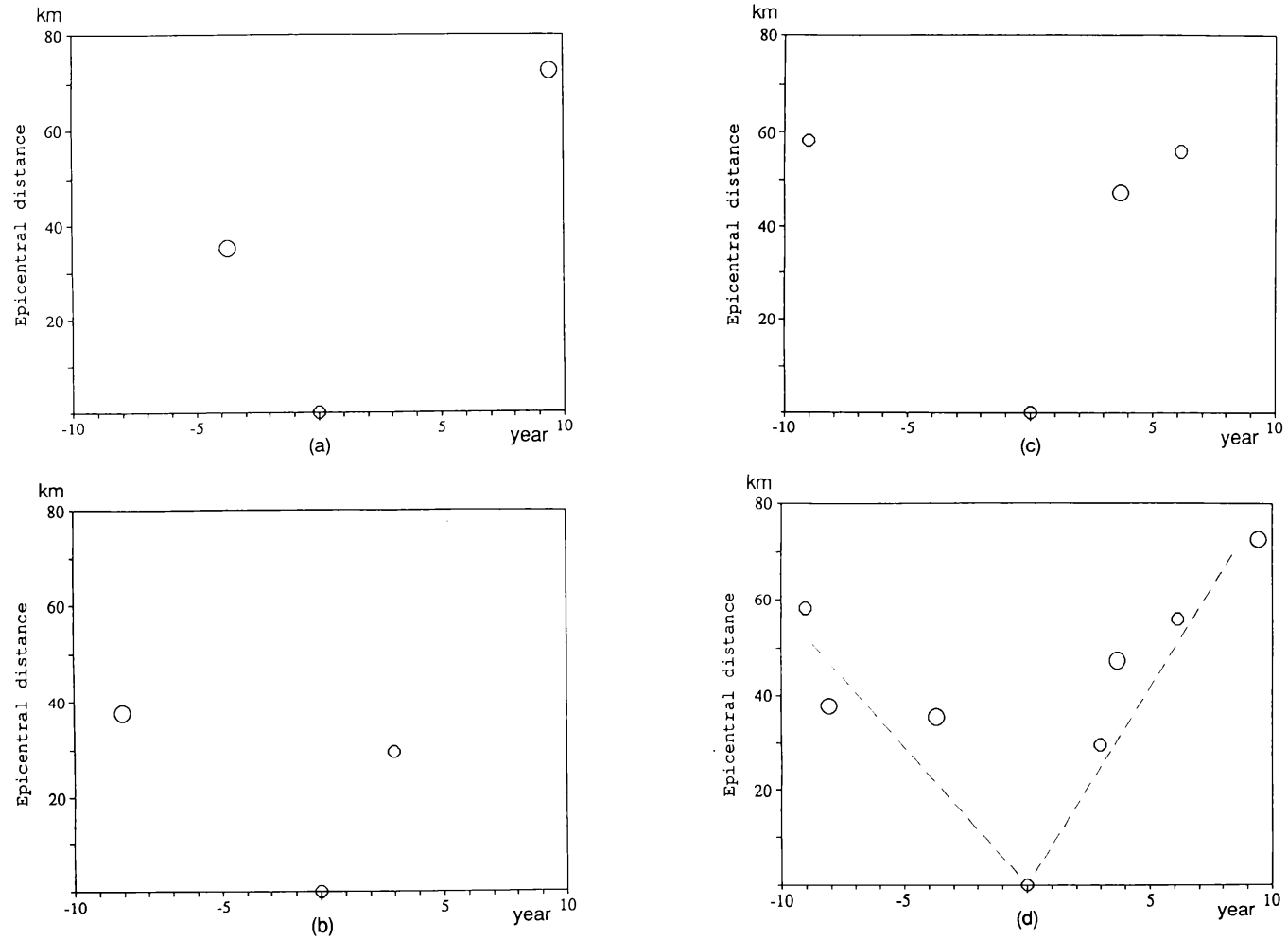

Fig. 2. Space-time distribution of earthquakes with $M \geqq 6$ which occurred around the epicenters of large earthquakes with $M \geqq 6.5$ : (a)the 1952 off-Daishoji earthquake; (b)the 1969 central Gifu prefecture earthquake; (c) the 1974 off-Izu Peninsula earthquake. Fig. 2(d) shows the superposition of Figs. 2(a), (b), and (c).
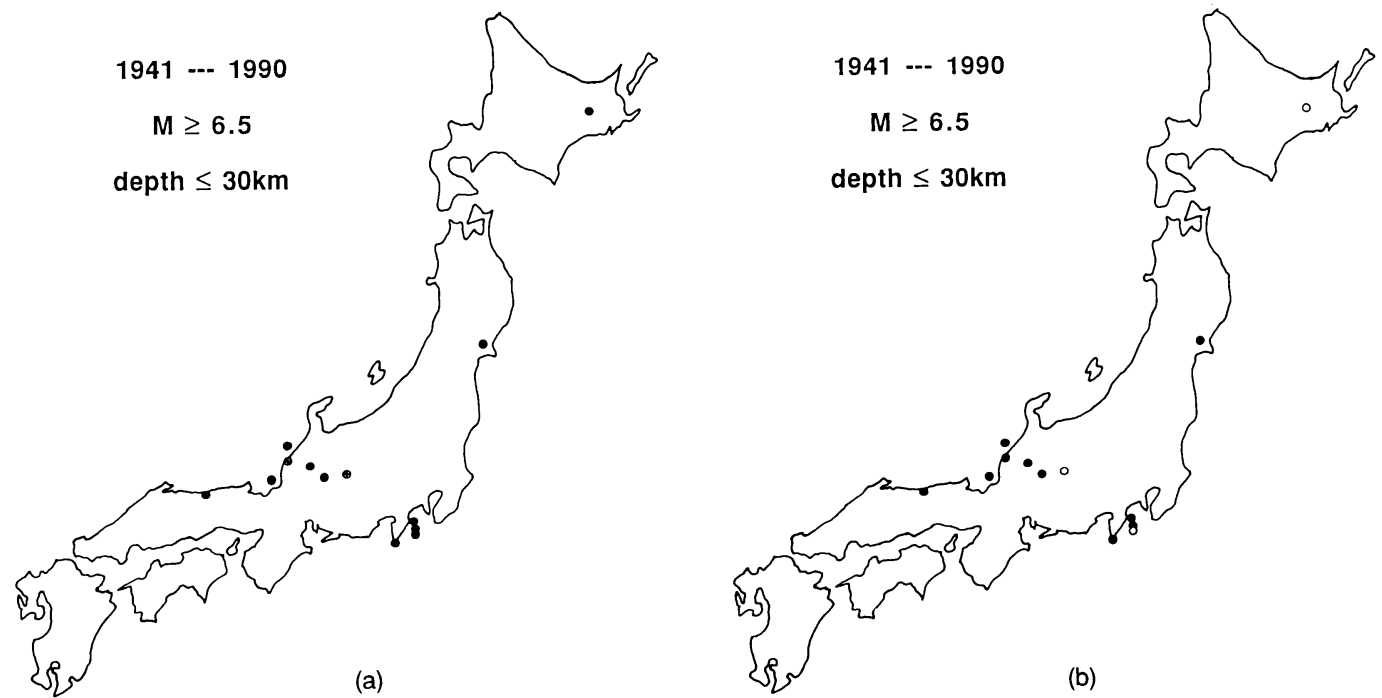

Fig. 3. (a) For all of the 13 earthquakes with $M \geqq 6.5$, large earthquakes with $M \geqq 6$ were observed at epicentral distances within $100 \mathrm{~km}$ and within 10 years (solid circles) or within 15 years (circles with cross) before their occurrence.

(b) For 10 of the 13 earthquakes with $M \geqq 6.5$, earthquakes with $M \geqq 6$ followed at epicentral distances within $100 \mathrm{~km}$ and within 10 years after their occurrence (solid circles). 


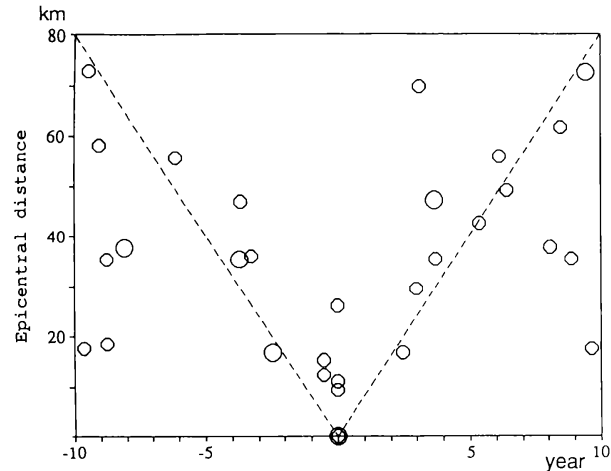

Fig. 4. Superposition of space-time distribution of earthquakes with $M \geqq 6$ which occurred around the epicenters of 13 large earthquakes with $M \geqq 6.5$. Dotted lines correspond to the migration velocity at $8 \mathrm{~km} /$ year.

は非常に稀で， $100 \mathrm{~km}$ 程度の範囲の中で見た場合，そ の前後約 10 年以内に $M 6$ 以上の地震を伴う確率が非常 に高いことを示している．これはテクトニックな一つの 単元, あるいは地域における内陸大地震の一種の続発性 を表すあのである.

次に, 先に触れた震央の移動傾向についてもう少し詳 しく検討してみよう. Fig. 4 は, Fig. 1 に示した 13 個の 地震それぞれについて Figs. 2(a), (b), (c) のような時空間 分布図をつくり，それらすべてを重ね合わせたものであ る. 点線は $8 \mathrm{~km} /$ 年の見かけ速度に対応している.ばら つきはあるあのの，ほぼそれに相当する速度で，震央が 中心となる地震に近づいてきて，またそれから遠ざかっ ていく傾向を認めることができよう.

Fig. 4 はテクトニクスや地質・地殼構造が異なる様々 な地域で発生した地震を区別することなく合成したもの であるが，例えば中部地方北西域や東北地方だけという ように地域を限定すると, 更に明瞭な移動傾向が見られ る.ただし，見かけの移動速度は，中部地方北西域では 約 $4 \mathrm{~km} /$ 年, 東北地方では約 $10 \mathrm{~km} /$ 年之, 地域によっ て多少異なる [YoshIDA (1992)]。 また, 東北地方の移動 系列では，ほぼ火山フロント沿いに北上していったのが 1962 年宮城県北部地震の後北西に向きを変えて, 1970 年秋田県南東部の地震が発生しているが，この方向の変 化には，茂木 (1985) が指摘しているように，男鹿-牡鹿 構造線の存在が影響を与えているものと思われる。 そし て, 中部地方北西域については, 長野県西部地震の後そ の北東側領域で地震活動が活発化しており [小林・他 (1992)], あし, 近い将来, この地域で大きな地震が発生 するとしたら，それは福井地震と長野県西部地震を結ぶ ゾーンの東側延長ではなく, 北信・上越地域で起きる可

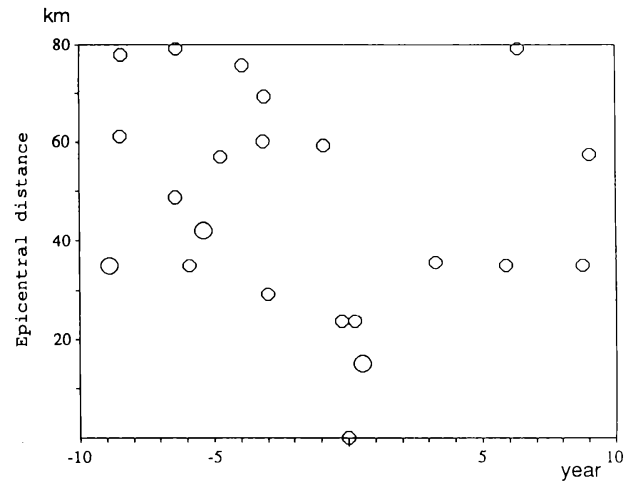

Fig. 5. Superposition of space-time distribution of earthquakes with $M \geqq 6$ around the epicenters of 19 earthquakes with $6.0 \leqq M \leqq 6.4$, which occurred during the period 1941 through 1990 in the Japanese islands.

能性が高いと推定される.

ここで, 内陸における $M 6.5$ 以上の大地震と $M 6$ ク ラスの地震とでは, その周辺地域の応力場の变化に対す る影響力の大きさに差があることを示す一つの事実を指 摘しておこう. Fig. 5 は, Fig. 1 と同期間の 1941〜 1990 年間に内陸に発生した $6.0 \leqq M \leqq 6.4 の 19$ 個の地 震について, Fig. 4 之同様に, その周辺の $M 6$ 以上の地 震の相対的な時空間分布を重ねて示したものであるが, 注目されるのは, Fig. 4 と異なって, これらの地震の後, $M 6$ 以上の地震が続いて発生する比率は著しく低いと いうことである.これは, 内陸における $M 6$ 程度の地震 は, 多くの場合, 更に別の $M 6$ 以上の地震を誘発するほ どの影響を周辺に及ぼさないということを示している.

\section{§3. 先駆的活動と静穏化}

Figs. 6(a), (b) はそれぞれ，1961 年北美濃地震, 1974 年伊豆半島沖地震を中心にとって, その前 25 年間, 後 25 年間, そして震央距離 $100 \mathrm{~km}$ 以内に発生した $M \geqq$ 4 , depth $\leqq 30 \mathrm{~km}$ の地震の時空間分布を示したものであ る.これらの図で共通に見られる特徴として, 震源の極 近傍で 10 年程前に先駆的地震らしきものが発生してい ること, それとほぼ同じ頃に震央距離 50〜 $100 \mathrm{~km}$ 付近 で活発な活動が見られること, 本震発生の直前は震源域 とそのすぐ周辺の地震活動が非常に低く，いわゆる静穞 化現象を呈していること等が挙げられる. 同じ様な特徵 を持つ岐阜県中部地震や福井地震についての時空間分布 あ合わせて，4つの地震に関する合成図をつくると, Fig. 8(a) に示すように，上で述べた特徴がより明瞭に認 められる. Fig. 8(a) ではまた, 本震発生後, 地震活動が 次第に周辺に移動・拡散していった傾向も見られる. 

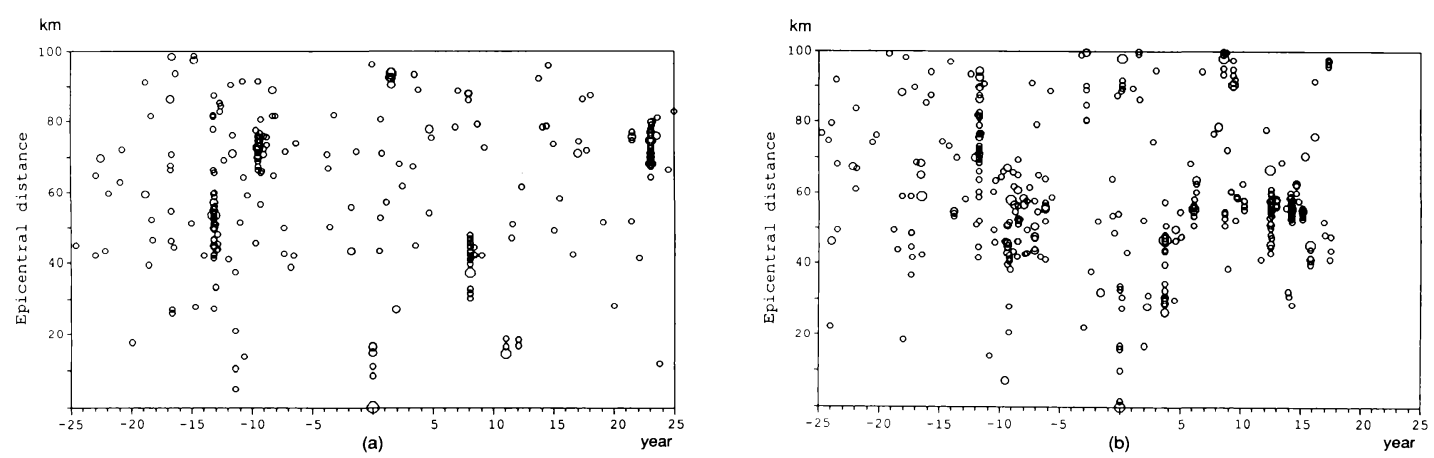

Fig. 6. Space-time distribution of earthquakes with $M \geqq 4$, depth $\leqq 30 \mathrm{~km}$, which occurred around the epicenters of the 1961 northern Mino earthquake (a); and the 1974 off-Izu Peninsula earthquake (b).
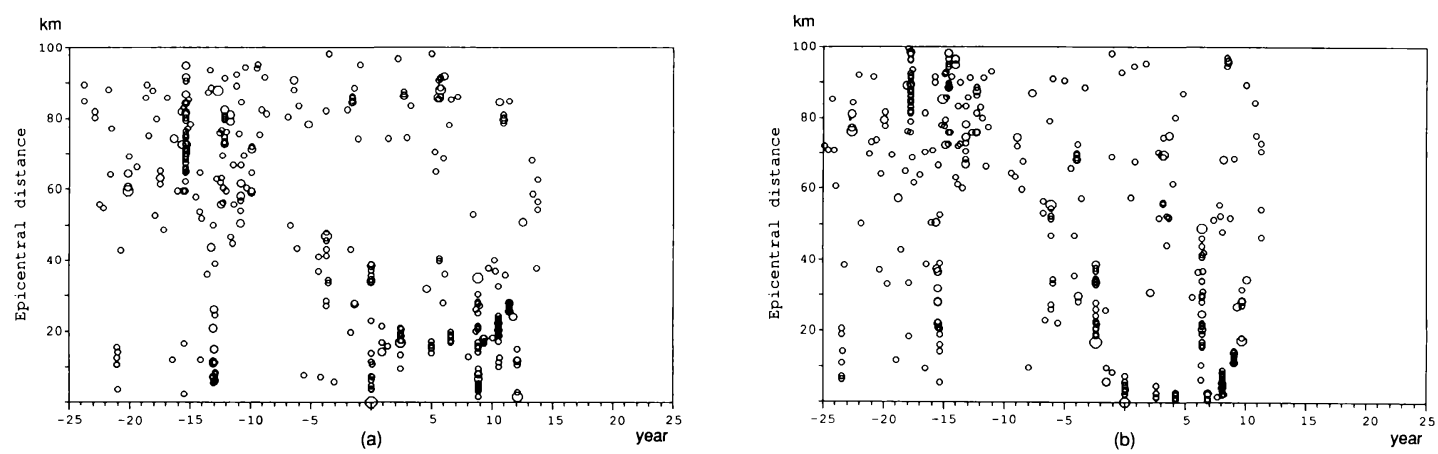

Fig. 7. Space-time distribution of earthquakes with $M \geqq 4$, depth $\leqq 30 \mathrm{~km}$, which occurred around the epicenters of the 1978 near Izu-Oshima earthquake (a); and the 1980 east-off Izu Peninsula earthquake (b).

一方, Figs. 7(a), (b) は, 1978 年伊豆大島近海地震, 1980 年伊豆半島東方沖地震について，それぞれ同様な 時空間分布を示したものである. パターンは Figs. 6(a), (b) と似ているが, よく見ると多少異なる，まず，震源域 周辺の先駆的地震活動は 15 年程前に起きており, 静榉 化はその活動の直後に顕著で, かつずっと広い範囲に及 んでいる，また，地震活動の移動傾向は，本震発生後よ りもむしろその前に認められ，上述の静穏化域が次第に 狭まってきて本震の発生に至っているように見える，共 通する特徵は, 本震の震源近傍で先駆的活動が見られる ちょうどその頃に, 周辺においても地震活動が活発化し ていることであるが，その区域は震央距離が 60〜90 km の付近と, Figs. 6(a), (b) の例に比べてやや外側にく る. Fig. 8(b) は, Figs. 7(a), (b) に大聖寺沖地震の場合を 合わせて 3 つの地震の時空間分布を合成したもので, こ れから上記の特徵は明らかであろう.

われわれは Fig. 8 の (a) と (b) で多少違いが見られる ということより, 地震活動の静稳化や活発化等の特徵が 共通して認められるということのほうにむしろ注目した いと思う。これらの特徴は一つ一つの地震について見た
場合には極めて明瞭とはいい難く，またすべての地震に ついての合成図をつくると, 静穏化の範囲や期間が地震 によって一定していないためにぼやけてしまうというこ とはあるが，それは，各地域で地震発生場や背景となる テクトニクスが異なることを考えれば，ある意味で当然 と思われる.

ところで, 震源から数 $10 \mathrm{~km}$ 付近のところに見られ る先駆的活動について触れておくと,これは一種のドー ナッパターンを表しているとみることができる. しか し，それはこの時の活動が震源域をとりまいて生じてい るということではない，むしろ特定の方向でのみ活動が 見られるというのが普通で, 多くの場合そこでは別の大 地震が発生している. この周辺域における先駆的活動と 同じ頃に，震源域近傍であ $M 5$ 程度の “先駆的”地震が 起きることがあるが (Figs. 6(a), (b) を参照)，これは数 $10 \mathrm{~km}$ 離れたところで発生した他の大地震に誘発され た地震とみることもできよう。時にはこれら二つの震源 域を結ぶゾーンに沿って地震活動が一時的に活発化する 現象も見られる.ただし，そのような場合，M6.5 程度 以上の大地震が直接誘発されて発生してしまうというこ 

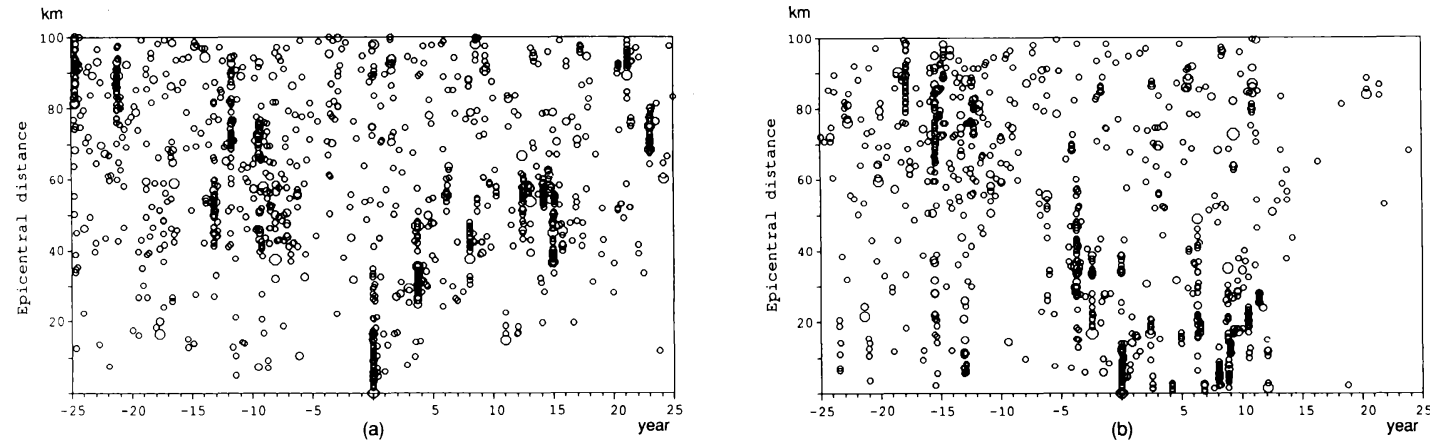

Fig. 8. (a) Superposition of space-time distribution of earthquakes with $M \geqq 4$, depth $\leqq 30 \mathrm{~km}$, which occurred around the 1961 northern Mino earthquake, the 1974 off-Izu Peninsula earthquake, the 1969 central Gifu prefecture earthquake and the 1948 Fukui earthquake.

(b) Superposition of space-time distribution of earthquakes with $M \geqq 4$, depth $\leqq 30 \mathrm{~km}$, which occurred around the 1978 near Izu-Oshima earthquake, the 1980 east off-Izu Peninsula earthquake and the 1952 off-Daishoji earthquake.
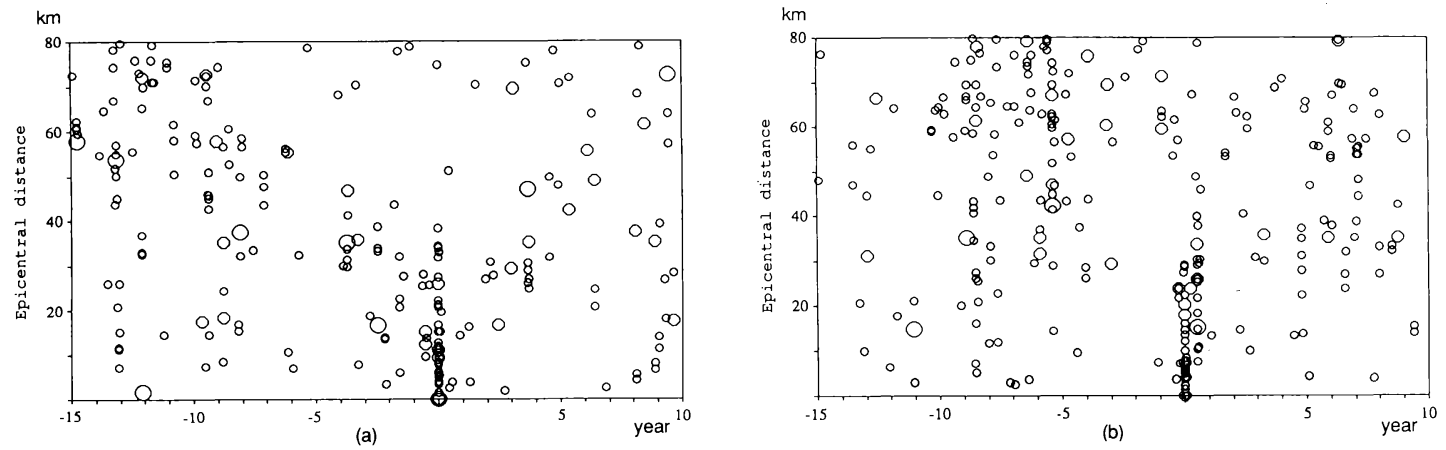

Fig. 9. (a) Superposition of space-time distribution of earthquakes with $M \geqq 5$ which occurred around the epicenters of 1.3 large earthquakes with $M \geqq 6.5$.

(b) Superposition of space-time distribution of earthquakes with $M \geqq 5$ which occurred around the epicenters of 19 earthquakes with $6.0 \leqq M \leqq 6.4$.

とは稀で, 応力場の擾乱を受けてからそうした地震が起 きるまでに, 通常何年かの年月を要するようである.（東 南海地震のような巨大地震の後では, $M 6.5$ クラスの地 震が短時日に引き続いて起こることあある）これに対し て, $M 6$ 程度の地震では, 数 $10 \mathrm{~km}$ 離れて起きた $M 7$ クラスの地震の影響がゆっくり及んできた段階で発生し たと見られるものもある [例えば小林・他(1992)].

内陸の $M \geqq 6.5$ の地震之, $6.0 \leqq M \leqq 6.4$ の地震の前後 の, その震源域周辺の地震活動のパターンの違いは, $M$ ミ5の地震について見た時にも顕著に認められる. Fig. 9(a) は, $M \geqq 6.5$ の 13 個の地震について, その前 15 年 間, 後 10 年間に発生した $M \geqq 5$ の地震の時空間分布を

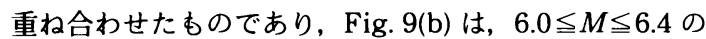
19 個の地震に関する同様な時空間分布の重ね合わせを 示したものである.これらの図を比較して気づく違い は, Fig. 9(b) では本震の前数年間, 震源域に倍する広い
範囲で顕著な空白域が認められるのに対して, Fig. 9(a) では，そうした空白域は本震の震源域付近で 5 年前頃を 中心に見られるということ，また，Fig. 9(a)では，これ までにも述べたように地震活動の移動パターンが認めら れるのに対して, Fig.9(b) ではそうした傾向は見られな いということであろう.

この他, Fig. 9(b) の特徵としては, 直前の空白域に加 えて, 5〜10 年前の周辺域における顕著な先駆的活動も 挙げられる.これがあるためにその後の空白域がより目 だったものとなっているということもできる，また，本 震の $5 \sim 8$ 年後にも，先駆的活動とほぼ対照的な形で後 発的な活動が認められる。これに対して, Fig.9(a)では, $8 \sim 13$ 年前の先駆的活動に加えて，直前の $1 \sim 3$ 年前に 屯震源域の近くで活動が活発化している様子が見える. しかし，それは $M 6.5$ 以上のすべての地震に共通してい るわけではない.むしろ, Fig. 8(a) に示したように, 直 
前に静穏化が認められるような例のほうが多いことに注 意する必要がある。

このような点で，多くの地震について重ね合わせた Figs. 9(a), (b) が，そのまま個々の地震に関する周辺域の 活動パターンの特徴を表していると即断するのは正しく ない. しかし，例えば，Fig. 8 やFig. 9 に認められる先 駆的活動や静秲化, 活動の移動傾向などは, 内陸大地震 の震源域とその周辺における応力場の変化の平均的なパ ターンをある程度反映していると見てもよいのではなか ろうか. また, 勝又・浜田 (1985) の指摘したような, 震 源域における先行的地震は, 周辺域における先駆的活動 との関連で見るならば，内陸ブロック境界に沿う応力場 の一時的な高まりを示しているとも考えられる. 82 で 述べた大地震の続発性も考虑して, 一つの内陸大地震が 発生した後 $3 \sim 4$ 年の間に, $M 5$ 程度の地震を含む活動 がそれから数 $10 \mathrm{~km}$ 離れたところで見られた場合には, その近傍は次の大地震が発生する可能性のある場所とし て，一応注意する必要があるということになろう。

繰り返すが, $M 6.5$ 以上の内陸大地震の個々につい て， その震源域周辺で Fig. 8 や Fig. 9 のような活動パ ターンが常に見られるというわけではない，本論文で調 查対象とした 13 個の地震の中には，互いの共通項を探 すのが困難で，むしろ正反対のように見える例もある.

例えば, 1961 年越前岬沖地震の前には, 20 年以上の長 期間にわたって M 4 以上の地震がその震源域近傍で全 く起きていないが, 1990 年伊豆大島近海地震の場合に は, その前 10 数年間, $M 4$ 以上の地震で見ても, 非常に 活発な状態であった。しかし, 前者については, あっと 小さな地震まで含めると，その前数年間やや活動が活発 化していた形跡も見られる. 残念ながら, 初めに述べた ように, M 4 よりあ小さな地震に関する活動パターンに ついては地震検知力の限界のために, 最近のいくつかの 地震を除いてはその特徴を系統的に論じることは困難で ある.これについては他日の研究を期したい.

\section{§4. まとめと議論}

1941 1990 年間に日本の内陸に発生した $M 6.5$ 以上 の大地震の震源域周辺の地震活動を調べて, 次の特徴を 明らかにした。

1. 多くの場合, その前後 10 年以内, 震央距離 100 $\mathrm{km}$ 以内に $M 6$ 以上の地震を伴っている.

2. 地震活動が数 $\mathrm{km} /$ 年の速度で移動していく傾向 が認められる.

3. $8 \sim 10$ 年前に震央距離 $50 \sim 100 \mathrm{~km}$ 付近で先駆的 活動が見られる. また，それとほぼ同時期に，震源域近 くでもM 4 5 の地震が起きている場合がある.
4. 震源域とその近傍では, 先駆的活動の後，一般に 地震活動が静穏化する．その静穏化は本震の直前まで続 くこともあるが, 1 ～3 年前に震源の隣接域で活動が活 発化する場合あある.

5. 内陸の $M 6.5$ クラスの大地震と $M 6$ クラスの地 震とでは, 周辺の応力場に与える影響の大きさに差が認 められる.

6. $M 6$ クラスの地震では， $M 5$ 程度以上の地震につ いて見た場合, 震源域周辺の広い範囲が, その発生前, 顕著に静穏化している.

7. $M 6$ クラスの地震の場合, その後, 周辺 $100 \mathrm{~km}$ 程度の範囲で 10 年以内に別の $M 6$ クラスの地震が引き 続いて発生する比率は低い.

本論文の目的は, 内陸大地震の震源域周辺の活動の中 に，予知に役立つ共通した性質を見いだすこと，あるい は，たとえ実用的な予知には有効でないとしても，震源 域の形成過程を理解するうえで意味のある特徴的なパ ターンを抽出することであった．前者の目的に関して は，まず上の 1 の特徴を挙げたい，この性質だけを基 に, 近い将来に内陸で $M 6$ 以上の地震が発生する可能 性のある場所をすべてピックアップすることはできない が，そうした場所の候補地を探すうえで有力な手がかり にはなろう。また， 2 及び 3 は，一つの大地震が発生し た後, 次にその周辺のよ゙のあたりに注目すべきかについ てヒントを与えるものである.

関谷 (1976) や勝又・浜田 (1985) が指摘している震源 域近くの先駆的地震は, $M 5$ 以上の地震ということに 限っても，13 例中 9 例ある（震央距離 $20 \mathrm{~km}$ 以内を とった時).ただしその発生時期は 2 年前から 13 年前に わたっていて，時間的な分布に集中性はない，M 4 以上 の地震をとれば，越前岬沖地震を除いてあと 12 例の場 合に，震源の近傍で活動が見られる。しかし，それは多 くの場合，顕著なむのとはいえず，これだけから実用的 な意味で発生場所を予測するのは難しいだろう。ここで は, この震源近傍における地震発生が, しばしば震央距 離 50 80 km 付近の先駆的活動々関連していること に, 特に注意したい，それは, これら二つの震源域を結 ぶゾーンに沿う活動として現れることもあり，更に，そ の活動がゆっくりと伝わっていったと見られる場合もあ る. 内陸における $M 6.5$ 以上の大地震は, かなり広い範 囲にわたって応力場の再編成を生じさせるようである [たとえば吉田・他 (1993)；小林・他 (1992)］が，それ を詳しく論じるには, 個々の地震の周辺のテクトニック なブロック構造や，もっと小さな地震まで含めた活動の 変化を注意深く調べる必要があろう。

上の 4 にあげた特徵, 本震直前まで静穏化が続く場合 
と, $1 \sim 3$ 年前に隣接域で活発化が見られる場合の二つ のタイプがあるのは一見矛盾するようだが，震源域周辺 の地款構造の地域差, 特に heterogeneity の違いを考虑 に入れれば，整合的に理解することもできなくはないと 考えられる. 静穏化の出現は, 大地震を起こしうるほど の空間的スヶールで応力場が蓄積されていることを示 し，直前の活動は，その応力場か十分に高くなってきた ことを表していると見ることあできよう.いずれにして あ, M 4 程度以上の地震活動だけから, 内陸大地震の震 源域形成過程を解明することはできないが，本論文で明 らかにしたいくつかの特徵は, そのための手がかりにな ると思われる。

\section{文献}

Evison, F. F., 1977, The precursory earthquake swarm, Phys. Earth Planet. Interiors, 15, 19-23.

勝又 護・浜田信生, 1985, 内陸地震に先行した地震活 動（やや，長期的にみた場合), 地震学会講演予稿集, No. 1, 134-135.

Kellemer, J. and J. Savino, 1975, Distribution of seismicity before large strike-slip and thrust-type earthquakes, J. Geophys. Res., 80, 260-271.

小林昭夫・吉田明夫・高山博之，1992，1984 年長野県 西部地震後の北信及び上越地域への地震活動の移動, 地震 2, 45, 353-356.

宮岡一樹・吉田明夫, 1993 , 日本海溝沿いのプレート間 大地震の前の地震活動の静秪化之先駆的活動, 地震 2 , 45, 395-405.
MogI, K., 1969, Some features of recent seismic activity in and near Japan, 2, Activity before and after great earthquakes, Bull. Earthq. Res. Inst., Univ. Tokyo, 46, 53-74.

MoGr. K., 1979, Two kinds of seismic gaps, Pure Appl. Geophys., 117, 1172-1186.

茂木清夫, 1985,1983 年日本海中部地震 $(M 7.7)$ の発生 と東北日本のサイスモテクトニクス, 地震研彙報, 60 , 401-428.

Ohtake, M., T. Matsumoto and G. V. Latham, 1977 , Seismicity gap near Oaxaca, southern Mexico as a probable precursor to a large earthquake, Pure Appl. Geophys., 115, 375-385.

関谷 溥, 1976, 地震発生前の地震活動と地震予知, 地 震 2, 29, 299-311.

SeKIYA, H., 1977, Anomalous seismic activity and earthquake prediction, J. Phys. Earth, 25, Suppl., S 85-S93.

鈴木雄次, 1985 , 前震の記録, 発行者 鈴木雄次, 164 p.

高山博之・吉田明夫, 1992 , 関東・東海・近畿地域にお ける地震活動の相関について, 地震 2, 45, 247-254.

宇津徳治, 1972, 北海道周辺における大地震の活動と根 室半島沖地震について, 地震予知連絡会会報, 7,7-13.

YoshidA, A., 1992, Successiveness and migration of large intraplate earthquakes in the Japanese islands, Proceedings of the II International Conference on Continental Earthquakes, Beijing, in press. 吉田明夫・森 滋男・前田憲二・高山博之, 1993, 地震 発生場の状況変化の指標としての “前兆現象”, 地球惑 星科学関連学会 1993 年合同大会予稿集, 241 . 